\title{
NOTE ON A METHOD FOR DETERMINATION OF AMMONIA IN SEA WATER
}

\author{
By M. Buljan \\ Institut za Oceanografiju i Ribarstvo, Split, Jugoslavia
}

Since the estimation of ammonia in sea water by existing methods either presents difficulties or requires much time, an alternative based on a different principle has been explored.

This method depends upon the action of ammonia on sodium hypobromite in an alkaline medium, when

$$
2 \mathrm{NH}_{3}+3 \mathrm{NaBrO}=\mathrm{N}_{2}+3 \mathrm{NaBr}+3 \mathrm{H}_{2} \mathrm{O} .
$$

If the sea water is acidified before the hypobromite is added, the ammonia present will not react. The effect therefore may be measured of adding the hypobromite, in equal quantities, to two samples of sea water, one untreated and one acidified. The difference represents an equivalent of ammonia. Excess hypobromite is estimated colorimetrically by adding Bordeaux B dye solution, which is decolorized by the hypobromite in acid solution.

I have the pleasure to thank very gratefully $\mathrm{Dr} \mathrm{H}$. W. Harvey, F.R.S., to whom I am much indebted for suggesting the problem, for his criticism and contribution to the work. The discussions with Dr L. H. N. Cooper and Mr F. A. J. Armstrong were also very helpful and I thank them cordially.

This work was done at the Plymouth Laboratory, and I am deeply indebted to the Director, Mr F. S. Russell, F.R.S., for his kindness in allowing me unrestricted facilities in the Laboratory.

\section{Solutions Required}

\section{THE METHOD}

(i) Hydrobromic acid $0.23 \mathrm{~N}$, containing $\mathrm{I} \cdot 9 \% \mathrm{HBr}$. (ii) Sodium hypobromite $0.001 \mathrm{~N}$, made by diluting $0 . \mathrm{IN}$ stock solution, which is prepared by dissolving $2.5 \mathrm{~g}$. NaOH and $\mathrm{I} .25 \mathrm{ml}$. fluid bromine in $500 \mathrm{ml}$. of distilled water. This $0.00 \mathrm{IN}-\mathrm{NaBrO}$ is made alkaline by adding $\mathrm{I} \%$ of $2 \mathrm{~N}-\mathrm{Na}_{2} \mathrm{CO}_{3}$. (iii) Bordeaux B, $0.014 \mathrm{~g}$. of dye per litre. (iv) Ammonium sulphate: stock solution; $0.4716 \mathrm{~g}$. $\left(\mathrm{NH}_{4}\right)_{2} \mathrm{SO}_{4}$ per litre; working solution is obtained by diluting $4 \mathrm{ml}$. of stock solution to $500 \mathrm{ml}$. $0.25 \mathrm{ml}$. of this solution contains $2 \mu$ g. ammonia-N. 


\section{Procedure}

Exactly $50 \mathrm{ml}$. of the sea-water sample is transferred to each of three IOO-I $50 \mathrm{ml}$. flasks by pipette. Using an all-glass syringe (Krogh's pipette) there is then added to

flask A: I ml. of (i) solution, followed immediately by $2 \mathrm{ml}$. of (ii) solution, followed immediately by $5 \mathrm{ml}$. of (iii);

flask B: $2 \mathrm{ml}$. of (ii) and then after I min.

I ml. of (i) followed immediately by $5 \mathrm{ml}$. of (iii);

flask C: $0.25 \mathrm{ml}$. of (iv) (which is equivalent to the addition of $40 \mathrm{mg}$. ammonia- $\mathrm{N} / \mathrm{m} .^{3}$ ) and thereafter as for flask B.

The flasks are allowed to stand covered for $2 \mathrm{hr}$. or more (overnight) and the absorption of blue green light is then measured. Colorimetric measurements are conveniently made in a $4 \mathrm{~cm}$. cuvette in the instrument described by Harvey (I948), the light passing through two Ilford filters, no. 404R+ no. 403 R.

If $\alpha, \beta$ and $\gamma$ is the increase in optical density over that of distilled water, of the contents of the three flasks in the same cuvette, then $\beta-\alpha=K \times$ hypobromite destroyed by ammonia present in the water sample, and $\gamma-\beta=K \times$ hypobromite destroyed by the added $40 \mathrm{mg}$. ammonium-N/m. ${ }^{3}$.

The concentration of ammonia in the sample of sea water is therefore $\frac{40(\beta-\alpha)}{\gamma-\beta} \mathrm{mg}$. ammonia-N/m. ${ }^{3}$.

\section{Example}

The following shows a typical analysis carried out in triplicate on a sample of sea water collected from offshore:

Difference in Optical Density in $4 \mathrm{~cm}$. Cuvette, Compared with Distilled Water

$\begin{array}{lcccc}\text { Exp. } & & & \frac{40(\beta-\alpha)}{\gamma-\beta} \\ \text { I } & \alpha & \beta & \gamma & \text { ammonia-N/m. } \\ \text { II } & 0.305 & 0.338 & 0.38 \text { I } & 30.7 \\ \text { III } & 0.302 & 0.335 & 0.376 & 32.2 \\ \text { IV } & 0.298 & 0.332 & 0.380 & 28.3 \\ & 0.306 & 0.339 & 0.374 & 37.7\end{array}$

The values of $\alpha$ in this experiment indicated that $64 \%$ of the added dye had been decolorized.

The $\alpha$ value varies with the concentration of hypobromite solution, which 
decreases with age; it also varies with different sea-water samples, being greater for harbour waters.

The value of $\gamma-\beta$ bears a strict linear relation to the quantity of ammonia nitrogen added up to a total of about $\mathrm{I} 40 \mathrm{mg}$. N-NH $\mathrm{N}_{3} / \mathrm{m}^{3}$ present. The estimated value of ammonia nitrogen is not affected by the addition of $10 \mathrm{mg} . / 1$. of glucose and is not significantly affected by the addition of $40 \mathrm{mg}$. nitrite nitrogen per $\mathrm{m}^{3}$. When amino-acetic acid is added, about $30 \%$ of the amino-nitrogen behaves as ammonia. During storage the ammonia content of unfiltered sea waters was found to decrease, as had been observed by Redfield \& Keys (1938).

\section{Comparison with Determinations Made by Distilling Sea Water in a Current of Air under Reduced Pressure}

The method of Krogh (I934) was followed, $30 \mathrm{ml}$. of sea water (at pH IO-I I obtained by adding $0.25 \mathrm{~N}-\mathrm{NaOH}$, using cresol phthalein as indicator) being distilled in a current of air at a pressure of $70-80 \mathrm{~mm}$. mercury.

The use of a $0.006 \%$ solution of potassium indigo disulphonate, instead of napthyl red, gave a sharper end-point and obviated the necessity of titrating each sample at the same speed and of thoroughly cleaning the titration vessels in order to rid them of all traces of oxidation products of napthyl red. Traces of these products interfere with the titration (Buljan, I95I).

It was found that if amino-acetic acid was added to the sea water, I6-20\% of the amino-nitrogen distilled over as ammonia. Hence in both methods, the estimated values for ammonia nitrogen include a part of any amino-nitrogen present. Determinations carried out by the distillation method, in duplicate from the same sample of unfiltered sea water, did not show close agreement, sometimes differing by as much as II mg. ammonia-N/m. ${ }^{3}$.

The following table gives results (in $\mathrm{mg}$. ammonia-N/m. ${ }^{3}$ ) obtained by the two methods:

\begin{tabular}{|c|c|c|}
\hline . & $\underset{\text { distillation }}{\mathrm{By}}$ & $\begin{array}{c}\text { By } \\
\text { photometric } \\
\text { method }\end{array}$ \\
\hline Raw unfiltered sea water collected offshore & $\begin{array}{l}29.9 \\
35.6 \\
25 \cdot 3 \\
2 \mathrm{I} \cdot 8\end{array}$ & $\begin{array}{l}37 \cdot 7 \\
30 \cdot 7 \\
32 \cdot 2 \\
28 \cdot 3\end{array}$ \\
\hline Mean & $28 \cdot 15$ & $32 \cdot 2$ \\
\hline $\begin{array}{l}\text { Another unfiltered sea water collected offshore } \\
\text { Stored water } \\
\text { Water from Plymouth Sound } \\
\text { Polluted sea water (a mixture of water from } \\
\text { densely populated aquarium and open sea water) }\end{array}$ & $\begin{array}{l}18 \cdot I^{\star} \\
16 \cdot 8^{\star} \\
27 \cdot 8^{\star} \\
40 \cdot 6^{\star}\end{array}$ & $\begin{array}{r}25 \cdot 5 \\
7 \cdot 5 \\
30 \cdot 8 \\
48 \cdot 0\end{array}$ \\
\hline $\begin{array}{l}\text { Plymouth Sound sea water with artificially } \\
\text { destroyed ammonia } \\
\text { Total of means }\end{array}$ & $\mathrm{I} 35 \cdot 35$ & I $44 \cdot 0$ \\
\hline
\end{tabular}

* Mean of duplicate determinations. 
The totals of the mean values, obtained by each method, are similar. Differences between replicate values appear to be due to similar experimental errors inherent in both methods.

The photometric method is more simple and rapid than distillation.

The time available for this investigation did not allow further study of discrepancies between the two methods.

\section{REFERENCES}

Buljan, M., 1951. Arhiv, Za Kemiju, Zagreb (in the Press).

HARveY, H. W., I948. The estimation of phosphate and of total phosphorus in seawaters. Fourn. Mar. Biol. Assoc., Vol. 27, pp. 337-59.

KROGH, A., I934. A method for the determination of ammonia in water and air. Biol. Bull. Woods Hole, Vol. 67, pp. I26-3I.

Redfield, A. C. \& Keys, A. B., I938. The distribution of ammonia in the waters of the Gulf of Maine. Biol. Bull. Woods Hole, Vol. 74, pp. 83-92. 